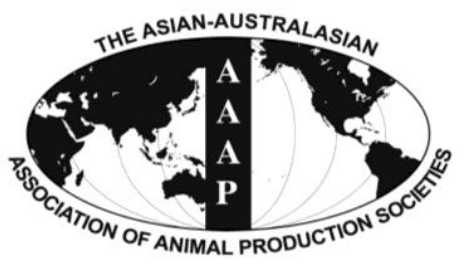

Asian-Aust. J. Anim. Sci.

Vol. 25, No. 11 : 1595-1604 November 2012

http://dx.doi.org/10.5713/ajas.2012.12339

www.ajas.info

pISSN 1011-2367 elSSN 1976-5517

\title{
Effects of Anti-diarrhoeal Herbs on Growth Performance, Nutrient Digestibility, and Meat Quality in Pigs
}

\author{
J. H. Cho, S. Zhang and I. H. Kim* \\ Department of Animal Resource and Science, Dankook University, Cheonan, Choongnam 330-714, Korea
}

\begin{abstract}
Two studies were conducted to investigate the effects of anti-diarrhoeal herbs on growth performance, nutrient digestibility, and meat quality in pigs. In Exp 1, 150 weanling-growing piglets (average BW $=7.5 \pm 0.24 \mathrm{~kg}$, average age $=27 \pm 1 \mathrm{~d}$ ) were allotted into one of the five dietary treatments, including: i) CON, basal diet, ii) DP, basal diet $+1 \mathrm{~g} / \mathrm{kg}$ date pits, iii) $\mathrm{JH}$, basal diet +0.5 $\mathrm{g} / \mathrm{kg}$ Japanese-honeysuckle, iv) HCT, basal diet $+1 \mathrm{~g} / \mathrm{kg}$ houttuynia cordata thunb, and v) LE, basal diet+1 g/kg laquer tree extract. From wk 0 to 5, the JH, HCT and LE groups presented higher (p<0.05) ADFI, ADG and gain/feed ratio (G/F) than CON and DP groups. During wk 5 to 10, Pigs fed JH, HCT and LE diets indicated higher $(\mathrm{p}<0.05)$ ADG and ADFI than the pigs fed CON and DP diets. During the entire experimental period, a significant increase of ADG appeared in JH, HCT and LE ( $<<0.05$ ). Pigs fed JH, HCT and LE diets got a higher $(\mathrm{p}<0.05)$ ADFI than the pigs fed CON and DP diets. Pigs fed diets with supplementations of herb additives revealled lower $(\mathrm{p}<0.05)$ score of diarrhea pigs during d 2 to d 6 compared with pigs fed CON diet. In Exp 2, 60 growing-finishing barrows and gilts (average $\mathrm{BW}=54.10 \pm 1.20 \mathrm{~kg}$, average age $=54 \pm 3 \mathrm{~d}$ ) were allotted to three treatments: i) CON, basal diet; ii) YG, basal diet+1 $\mathrm{g} / \mathrm{kg}$ yellow ginger and iii) HR, basal dietary $+1 \mathrm{~g} / \mathrm{kg}$ hoantchy root, respectively. From wk 0 to 5 , Dietary supplementation of YG and HR enhanced $(\mathrm{p}<0.05)$ ADG. No difference was found between YG and HR treatments. During, wk 5 to 10 , ADG also was observed higher in YG and HR treatments than CON group $(\mathrm{p}<0.05)$. Additional, YG had the highest ADG $(\mathrm{p}<0.05)$ among treatments. There was always an increase of ADG in YG and HR $(\mathrm{p}<0.05)$ through all periods. HR treatment showed a lower $(\mathrm{p}<0.05)$ score of diarrhoeal pigs on d land d 2 compared with CON treatment. Pigs fed YG and HR diets had a higher ( $<<0.05$ ) longissimus muscle area (LMA) than pigs fed CON diet. In conclusion, anti-diarrhoeal herbs can improve growth performance, and prevent diarrhea incidence in pigs, it can also increase LMA in finishing pigs. (Key Words: Anti-diarrhoeal Herbs, Blood Characteristics, Growth Performance, Meat Quality, Pigs)
\end{abstract}

\section{INTRODUCTION}

Diarrhea is a big challenge for pork productions, especially at post-weanling phase resulted from the stress of weaning and movement to another environment increases the potential for disease, poor feed intake, and nutritional disorders (Kohler and Moon., 1984). Weanling piglets are associated with growth retardation as well as an increase in both morbidity and mortality in pigs (Wilson et al., 1989), due to an increase in the susceptibility to gram-negative bacterial infections (Nabuurs et al., 1995). Regarding the fact that weaning greatly affects general health condition of piglets, thereby it is necessary to supplement antibiotics in diets for alleviating the impacts of diarrhea. Indeed, after supplemented antibiotics, there is a substantial increase

\footnotetext{
* Corresponding Author: In Ho Kim. Tel: +82-41-550-3652, Fax: +82-41-565-2949, E-mail: inhokim@dankook.ac.kr Submitted Jun. 15, 2012; Accepted Jul. 16, 2012; Revised Jul. 29, 2012
}

in performance by enhancing immunity and decreasing the occurrence of diarrhea. However, as the growth of scientific research, exposure problems during production process, we came to realize the adverse influences, especially the development of resistant pathogenic bacterial strains and residual contamination of the food chain. In view of low residual contamination, low environmental pollution of natural raw materials, a increasing number of studies are focusing on phylogenic products that comprise a wide variety of herbs, spices, and essential oils (Windisch et al., 2008).

Some herbs additives are excellent anti-diarrhoeal drug which were demonstrated to be antioxidant (Nakatani, 2000; Wei and Shibamoto, 2007), antimicrobial (Si et al., 2006), and growth-promotor (Basmacioglu et al., 2004; Mao et al., 2005) in pigs. Those effects are partially associated with enhancing immunity, promoting anti-stress ability and increasing digestibility (Yen and Pond, 1993; 
Platel and Srinivasan, 1996; Hoshi et al., 1999). However, it's because of a mass of species of herbs, the complicated ingredients and uncertain specific mechanism, that the utilization of herbs is not well known.

Date pits, Japanese-honeysuckle (Lonicera Japanica), Houttuynia cordate thunb $(H$. cordate), Laquer tree (Rhus verniciflua Stokes), Yellow ginger (Dioscorea zingiberensis), Hoantchy root (Leguminosae) and Acanthopanax senticosus extract are used for anti-diarrhoeal, antiinflammatory, increasing appetite, antibacterial on human and livestock. (Jung., 1998; Hong et al., 1999; Mohamed and Chang., 2007; Yin et al., 2008) Enough reasons make us to evaluate the impacts of the traditional prescription which used as additives in pigs (Huo et al., 2004). We can hypothesis anti-diarrhoeal herbs are able to improve nutrient digestibility, growth performance and meat quality.

Therefore, the objective of the current study was to determine the effects of anti-diarrhoeal herbs on growth performance, nutrient digestibility, and meat quality in pigs.

\section{MATERIALS AND METHODS}

\section{Herbs substances}

As follow, the process of herbs additives in current experiment exhibited: while the herbs were taken into machine, the condition were controlled at moisture $15 \%$ to $17 \%, 70$ to $90^{\circ} \mathrm{C}$, and the pressure of water vapor at 220 to $500 \mathrm{kPa}$, temperature at 115 to $125^{\circ} \mathrm{C}$. At least, herbs were in an attrition mill to a size of 0.15 to $0.25 \mathrm{~mm}$. Main composition of the herbs used in the current experiment, were determined in accordance with the methods recommended by AOAC (1995).

In Exp 1, the compositions of data pits (DP) included 5.0 to $6.3 \%$ protein; 9.9 to $13.5 \%$ fat; 65 to $69 \%$ neutral detergent fibre and 1.0 to $1.8 \%$ ash. Mainly bioactive ingredients comprised dietary fibre, minerals, phytic acid, a-amylase inhibitors and tannins; The ingredients of Japanese-honeysuckle $(\mathrm{JH})$ were 1.6 to $2.1 \%$ proteins, 1.5 to $2.3 \%$ lipids, 6.4 to $7.2 \%$ saccharides, 61 to $73 \%$ neutral detergent fibre, and 0.5 to $1.1 \%$ ash. Mainly bioactive ingredients included green orthoacid, glycoside, flavonoid, volatile oils. Houttuynia cordata thumb (HCT) compromised 2.3 to $21 \%$ proteins, 1.1 to $2.3 \%$ lipids, 74 to $80 \%$ neutral detergent fibre, and 1.6 to $2.1 \%$ ash. Mainly bioactive compositions consist of lauric aldehyde, a-pinene, linlool, quercitrin, isoquercitrin. Laquer tree extracts (LE) included 3.7 to $4.2 \%$ proteins, 5.1 to $6.3 \%$ fat, 63 to $79 \%$ neutral detergent fibre and 1.3 to $2.1 \%$ ash, mainly bioactive components involved flavones, fisetin, arachidic acid, butein.

In Exp 2, Yellow ginger (YG) compromised 1.3 to $2.4 \%$ proteins, 2.1 to $2.6 \%$ lipids, 61 to $75 \%$ neutral detergent fibre, and 1.2 to $1.6 \%$ ash. Bioactive component consisted of curcumin, flavonoid glycoside. Hoantchy root (HR) included 3.2 to $4.3 \%$ proteins, 1.9 to $2.6 \%$ lipids, 57 to $72 \%$ neutral detergent fibre, and 1.4 to $1.9 \%$ ash. The mainly bioactive substance composed flavones, astragalus polysaccharides, ehilme and betaine.

\section{Experimental design, animals and diets}

The animal care and use protocol was approved by the Animal Care and Use Committee of Dankook University. In experiments (Landrace $\times$ Yorkshire $\times$ Duroc) crossbred pigs were allotted to treatments in randomized complete block designs according to the initial BW. Pigs were housed in an environmentally controlled nursery room with pens and plastic completely slotted flooring. Each pen was equipped with a self-feeder and a nipple drinker to allow ad libitum access to feed and water throughout the experimental period. All diets based on corn and soybean meal were provided in mash form and formulated to meet or exceed the NRC (1998) recommendations for all nutrient requirements (Tables 1, 2 and 3). Treatment additive was included in the diet by replacing the same amount of corn.

\section{Experiment 1}

A total of 150 weanling pigs (average $\mathrm{BW}=7.5 \pm 0.36$ $\mathrm{kg}$, average age $=27 \pm 1 \mathrm{~d}$ ) were allotted into one of five

Table 1. The diet composition of weanling pigs (as-fed basis)

\begin{tabular}{lr}
\hline Ingredient $(\%)$ & \\
\hline Corn & 55.55 \\
Soybean meal $(44 \% \mathrm{CP})$ & 24.96 \\
Whey powder & 6.00 \\
Fish meal $(64 \% \mathrm{CP})$ & 5.00 \\
Soybean oil & 2.08 \\
Spray-dried poroine plasma $(78 \% \mathrm{CP})$ & 3.00 \\
Dicalcium phosphate & 0.65 \\
Limestone & 1.00 \\
Salt & 0.25 \\
L-lysine HCl & 0.15 \\
DL-methionine & 0.04 \\
Vitamin and mineral premix ${ }^{\mathrm{a}}$ & 1.00 \\
L-threonine & 0.02 \\
Chemical composition ${ }^{\mathrm{b}}$ & \\
ME $(\mathrm{kcal} / \mathrm{kg})$ & 3,450 \\
CP $(\mathrm{g} / \mathrm{kg})$ & 21.1 \\
Methionine & 0.4 \\
Lys $(\mathrm{g} / \mathrm{kg})$ & 1.45 \\
Ca $(\mathrm{g} / \mathrm{kg})$ & 0.82 \\
P (g/kg) & 0.66 \\
\hline
\end{tabular}

${ }^{a}$ Provided the following per kilogram of complete diet: vitamin A, 12,000 IU; vitamin $\mathrm{D}_{3}, 2,500 \mathrm{IU}$; vitamin $\mathrm{E}, 30 \mathrm{IU}$; vitamin $\mathrm{K}_{3}, 3 \mathrm{mg}$; vitamin $\mathrm{B}_{12}, 0.012 \mathrm{mg}$; riboflavin, $4 \mathrm{mg}$; niacin, $40 \mathrm{mg}$; pantothenic acid, $15 \mathrm{mg}$; choline chloride, $400 \mathrm{mg}$; folic acid, $0.7 \mathrm{mg}$; thiamin, $1.5 \mathrm{mg}$; pyridoxine, $3 \mathrm{mg}$; biotin, $0.1 \mathrm{mg}$; Zn, $105 \mathrm{mg}$; $\mathrm{Mn}, 22 \mathrm{mg}$; Fe, $84 \mathrm{mg}$; Cu, $225 \mathrm{mg}$; I, $0.50 \mathrm{mg}$; and $\mathrm{Se}, 0.35 \mathrm{mg}$.

${ }^{\mathrm{b}}$ All calculated values are based on NRC (1998) tabular values. 
Table 2. The diet composition of growing pigs (as-fed basis)

\begin{tabular}{lr}
\hline Ingredient (\%) & 64.25 \\
\hline Corn & 26.63 \\
Soybean meal (CP 44\%) & 5.00 \\
Rice bran & 5.00 \\
Molasses & 4.67 \\
Animal fat & 1.55 \\
Defluorinated phosphate & 0.68 \\
Calcium carbonate & 0.12 \\
L-lysine·HCl & 0.20 \\
Salt & 0.06 \\
Vitamin and mineral premix ${ }^{\mathrm{a}}$ & 0.04 \\
Choline chloride & 0.02 \\
L-threonine & \\
Chemical composition & \\
ME (kcal/kg) & 3,320 \\
CP $(\%)$ & 18.00 \\
Lys (\%) & 1.00 \\
Methionine (\%) & 0.28 \\
Ca (\%) & 0.70 \\
P (\%) & 0.60
\end{tabular}

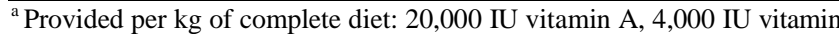
$\mathrm{D}_{3}, 80 \mathrm{IU}$ vitamin $\mathrm{E}, 16 \mathrm{mg}$ vitamin $\mathrm{K}_{3}, 4 \mathrm{mg}$ thiamin, $20 \mathrm{mg}$ riboflavin, $6 \mathrm{mg}$ pyridoxine, $0.08 \mathrm{mg}$ vitamin $\mathrm{B}_{12}, 120 \mathrm{mg}$ niacin, $50 \mathrm{mg} \mathrm{Ca}$ pantothenate, $2 \mathrm{mg}$ folic acid, $0.08 \mathrm{mg}$ biotin, $140 \mathrm{mg} \mathrm{Cu}, 179 \mathrm{mg} \mathrm{Zn}$, $12.5 \mathrm{mg} \mathrm{Mn}, 0.5 \mathrm{mg} \mathrm{I}, 0.25 \mathrm{mg}$ Co and $0.4 \mathrm{mg} \mathrm{Se}$.

${ }^{\mathrm{b}}$ All calculated values are based on NRC (1998) tabular values.

dietary treatments, including: i) CON, basal diet; ii) DP, basal diet+1 g/kg date pits and iii) $\mathrm{JH}$, basal diet+0.5 g/kg Japanese-honeysuckle; iv) HCT, basal diet+1 $\mathrm{g} / \mathrm{kg}$ houttuynia cordata thunb and v) LE, basal diet+1 $\mathrm{g} / \mathrm{kg}$ laquer tree extract. There were 6 pigs per pen, 5 replications per treatment. Each pen size was $0.6 \times 1.2 \mathrm{~m}$. The experiment lasted for $10 \mathrm{wks}$. The pigs were housed in a complete temperature and humidity controlled room and the initial room temperature was maintained at $30^{\circ} \mathrm{C}$ and decreased by $1^{\circ} \mathrm{C}$ each week of the experiment.

\section{Experiment 2}

Sixty growing-finishing pigs (average BW $=54.10 \pm 1.20$ $\mathrm{kg}$, average age $=54 \pm 3 \mathrm{~d}$ ) were allotted into 1 of the 3 treatments: i) CON, basal diet; ii) YG basal diet+1 $\mathrm{g} / \mathrm{kg}$ yellow ginger and iii) HR basal dietary+1 $\mathrm{g} / \mathrm{kg}$ hoantchy root. There were 4 pigs per pen, 5 replications per treatment. The experiment lasted for 10 wks. Pigs were housed in a complete temperature and humidity controlled room. During the growing phase, pigs were housed by pens $(1.2 \times 1.6 \mathrm{~m})$, and the temperature was kept at $26^{\circ} \mathrm{C}$. when the finishing phase, Pen size were $1.8 \times 1.8 \mathrm{~m}$. And the room temperature was maintained at $22^{\circ} \mathrm{C}$.

\section{Sampling and measurements}

Experiment 1 : During the experimental periods,
Table 3. The diet composition of finishing pigs (as-fed basis)

\begin{tabular}{lc}
\hline Ingredient $(\%)$ & 67.45 \\
\hline Corn & 18.14 \\
Soybean meal $(\mathrm{CP} 44 \%)$ & 5.00 \\
Rice bran & 5.00 \\
Molasses & 2.00 \\
Animal fat & 1.12 \\
Defluorinated phosphate & 0.68 \\
Calcium carbonate & 0.20 \\
L-lysine $\cdot \mathrm{HCl}$ & 0.15 \\
Salt & 0.05 \\
Vitamin premix ${ }^{\mathrm{a}}$ & 0.15 \\
Mineral premix & \\
Choline chloride & 0.04 \\
L-threonine & 0.02 \\
Chemical composition & \\
ME $(\mathrm{kcal} / \mathrm{kg})$ & \\
CP $(\mathrm{g} / \mathrm{kg})$ & 3,350 \\
Lys $(\mathrm{g} / \mathrm{kg})$ & 14.80 \\
Ca $(\mathrm{g} / \mathrm{kg})$ & 0.89 \\
$\mathrm{P}(\mathrm{g} / \mathrm{kg})$ & 0.74 \\
Provided per & 0.54 \\
\hline
\end{tabular}

${ }^{a}$ Provided per kg of complete diet: 4,000 IU of vitamin A; 800 IU of vitamin $\mathrm{D}_{3} ; 17 \mathrm{IU}$ of vitamin $\mathrm{E} ; 2 \mathrm{mg}$ of vitamin $\mathrm{K} ; 4 \mathrm{mg}$ of vitamin $\mathrm{B}_{2} ; 1 \mathrm{mg}$ of vitamin $\mathrm{B}_{6} ; 16 \mu \mathrm{g}$ of vitamin $\mathrm{B}_{12} ; 11 \mathrm{mg}$ of pantothenic acid; $20 \mathrm{mg}$ of niacin and $0.02 \mathrm{mg}$ of biotin.

${ }^{\mathrm{b}}$ Provided per kg of complete diet: $220 \mathrm{mg}$ of $\mathrm{Cu} ; 175 \mathrm{mg}$ of Fe; $191 \mathrm{mg}$ of $\mathrm{Zn} ; 89 \mathrm{mg}$ of $\mathrm{Mn} ; 0.3 \mathrm{mg}$ of I; $0.5 \mathrm{mg}$ of Co and 0.15 $\mathrm{mg}$ of Se.

${ }^{c}$ All calculated values are based on NRC (1998) tabular values.

individual body weight and feed consumption per pen were measured at the end of 5th and 10th week to monitor ADG, ADFI and gain:feed ratio (G/F).

For each piglet showing scours, diarrhoea was assessed visually and characterised, by the same person, according to the following scale as: $0=$ normal faeces, $1=$ pasty, $2=$ liquid, 3 = with mucus and $4=$ with blood. The daily diarrhoea score for each pen was calculated by multiplying each piglet by the previous characterization scale of diarrhoea, and the results for all piglets within a pen were then added together. Diarrhoea scores were calculated by day. The maximum theoretical diarrhoea score was 24 (6 pigs $\times$ scale $4=24$ ).

Experiment 2 : The pigs and feeders were weighed at the beginning, the 5th wk and at 10th wk of the growth assay to allow calculation of ADG, ADFI and G/F.

For each pigs showing diarrhoea, the severity was assessed visually and characterized, by the same person, according to the following scale as: $0=$ normal faeces, $1=$ pasty, 2 = liquid, $3=$ with mucus and $4=$ with blood (Kyriakis et al., 1999). The total diarrhoea score on a pen basis was calculated as the sum of the number of piglets in the pen with diarrhoea multiplied by the days of observations and multiplied by the diarrhoea scale observed 
in the majority of the pigs in the pen. Diarrhoea scores were calculated by day. The maximum theoretical diarrhoea score was 16 ( 4 pigs $\times$ scale $4=24)$.

Chromium oxide $\left(\mathrm{Cr}_{2} \mathrm{O}_{3}\right)$ was added to each of the diet as an inert indicator $(0.20 \%)$ to calculate the apparent total tract digestibility (ATTD) for dry matter (DM), nitrogen (N) and energy during each dietary phase. After the pigs were fed diet containing the indicator for $5 \mathrm{~d}$, fresh fecal grab samples were obtained from 2 pigs (one barrow and one gilt) per pen. All fecal and feed samples from one pen were then pooled and mixed, after which a representative sample was stored in a freezer at $-20^{\circ} \mathrm{C}$ until analysis. Prior to chemical analysis, the fecal samples were thawed and dried at $70^{\circ} \mathrm{C}$ for $72 \mathrm{~h}$, after which they were finely ground to a size that could pass through a $1 \mathrm{~mm}$ sieve. All of the feed and fecal samples were then analyzed for DM and $\mathrm{N}$ following the procedures outlined by the AOAC (AOAC, 1995). Chromium was analyzed using UV absorption spectrophotometry (Shimadzu, UV-1201, Kyoto, Japan) and nitrogen was determined using a Kjeltec 2300 Analyzer (Foss Tecator AB, Hoeganaes, Sweden). Gross energy was determined by measuring the heat of combustion in the samples using a Parr 6100 oxygen bomb calorimeter (Parr instrument Co., Moline, IL, USA).

Blood samples were collected at cervical vein into both $\mathrm{K}_{3}$ EDTA vacuum tubes and clot activator vacuum tubes (Becton Dickinson Vacutainer Systems, Franklin Lakes, NJ, USA) from 2 pigs in each pen on $35 \mathrm{~d}$, and the same pigs were sampled again on the final day of the experiment. White blood cell (WBC), red blood cell (RBC), and lymphocytes counts were analyzed using an automatic blood analyzer (ADVIA 120, Bayer Corp). The IgG was analyzed using nephelometry (Dade Behring, Marburg, Germany).

At the end of the trial, all of the pigs were transferred to the slaughterhouse and were treated with conventional procedures. Carcasses were chilled at $2^{\circ} \mathrm{C}$ for $24 \mathrm{~h}$ and a piece of the right loin was taken through a perpendicular cut between 10th and 11th ribs. Before the meat quality evaluation was performed, meat samples were thawed at ambient temperature. The color measurement of lightness $\left(\mathrm{L}^{*}\right)$, redness $\left(\mathrm{a}^{*}\right)$ and yellowness $\left(\mathrm{b}^{*}\right)$ values were determined by Minolta CR410 chroma meter (Konica Minolta Sensing, Inc., Osaka, Japan). S he proportion of LM acceptable for Pork Composition and Quality Assessment Procedures (NPPC, 2000) was determined via the selection of LM with acceptable color, firmness, and marbling (all measures 3 or greater, based on a scale of 1 to 5, NPPC, 2000). At the same time, duplicate $\mathrm{pH}$ values of each sample were measured by $\mathrm{pH}$ meter (Pittsburgh, PA, USA). The water holding capacity (WHC) was measured according to the methods of Kauffman et al. (1986). In brief, $0.2 \mathrm{~g}$ sample was pressed at 3,000 psi for $3 \mathrm{~min}$ on 125 - mm-diameter filter paper. The areas of the pressed sample and expressed moisture were delineated and then determined with a digitizing arealine sensor (MT-10S; M.T. Precision Co. Ltd., Tokyo, Japan). A ratio of water: meat areas was calculated, giving a measure of WHC (the smaller ratio indicate the higher the WHC). Longissimus muscle area (LMA) was measured by tracing the longissimus muscle surface at 10th rib, which also used the abovementioned digitizing arealine sensor. Drip loss was measured using approximately $2 \mathrm{~g}$ of meat sample according to the plastic bag method, which was described by Honikel et al. (1998). The weight of each sample was taken before and after cooking to determine cooking loss, which was defined as the cooked weight divided by uncooked weight multiplied by 100 .

\section{Statistical analyses}

All data were subjected to the GLM procedures of SAS (1996) as a randomized complete block design, with pen as the experimental unit. Differences among all treatments were separated by Duncan's multiple range test. The variability in the data was expressed as standard error (SE) Probability values less than 0.05 were considered significant.

\section{RESULTS}

\section{Experiment 1}

Growth performance : Effects of herbs on growth performance in weanling-growing pigs were shown in Table 4. Pigs fed JH, HCT and LE diets revealled a higher ( $\mathrm{p}<$ 0.05) $\mathrm{BW}$ on wk 5 and wk 10 than pigs fed $\mathrm{CON}$ and $\mathrm{JH}$ diets. The ADG in JH, HCT and LE treatments was enhanced $(p<0.05)$ compared with that in CON and DP treatments during weaning and growing period. On wk 5, pigs had a higher $(\mathrm{p}<0.05)$ ADFI in LE treatment compared with CON and DP treatments, besides pigs fed JH, HCT and LE diets had a higher $(\mathrm{p}<0.05) \mathrm{G} / \mathrm{F}$ ratio than pigs fed CON and DP diets. Furthermore, form wk 5 to 10 , JH, HCT and LE treatment groups had a higher $(\mathrm{p}<0.05)$ ADFI compared with CON and DP treatment groups.

Appearance of diarrhea : Pigs fed diets with supplementations of herb additives had lower $(p<0.05)$ score of diarrhea pigs during d 2 to d 6 compared with pigs fed CON diet (Table 5). On d 2 and 3, HCT and LE exhibited lower diarrhea score than DP and JH $(\mathrm{p}<0.05)$. No difference was found among herb additives groups on $\mathrm{d} 5$ and $6(\mathrm{p}>0.05)$

\section{Experiment 2}

Growth performance and Apparent total tract nutriment digestibility : Effects of herbs on growth performance in growing-finishing pigs were shown in Table 6. From wk 0 
Table 4. Effect of anti-diarrhoeal herbs on growth performance, in weanling-growing pigs ${ }^{1}$

\begin{tabular}{|c|c|c|c|c|c|c|}
\hline Items & $\mathrm{CON}$ & DP & $\mathrm{JH}$ & HCT & $\mathrm{LE}$ & $\overline{\mathrm{SE}^{2}}$ \\
\hline Initial BW (kg) & 7.17 & 7.34 & 7.21 & 7.33 & 7.19 & 0.13 \\
\hline $5 \mathrm{w}(\mathrm{kg})$ & $24.26^{\mathrm{b}}$ & $24.82^{\mathrm{b}}$ & $28.29^{\mathrm{a}}$ & $28.10^{\mathrm{a}}$ & $29.20^{\mathrm{a}}$ & 1.65 \\
\hline $10 \mathrm{w}(\mathrm{kg})$ & $46.94^{\mathrm{b}}$ & $47.25^{\mathrm{b}}$ & $53.25^{\mathrm{a}}$ & $52.36^{\mathrm{a}}$ & $54.33^{\mathrm{a}}$ & 2.14 \\
\hline \multicolumn{7}{|l|}{0 to $5 \mathrm{w}$} \\
\hline $\operatorname{ADG}(\mathrm{g})$ & $488^{\mathrm{b}}$ & $499^{\mathrm{b}}$ & $602^{\mathrm{a}}$ & $593^{\mathrm{a}}$ & $629^{a}$ & 17 \\
\hline ADFI (g) & $613^{\mathrm{b}}$ & $658^{\mathrm{b}}$ & $681^{\mathrm{ab}}$ & $673^{\mathrm{ab}}$ & $731^{\mathrm{a}}$ & 53 \\
\hline $\mathrm{G} ; \mathrm{F}$ & $0.796^{\mathrm{b}}$ & $0.758^{\mathrm{b}}$ & $0.884^{\mathrm{a}}$ & $0.881^{\mathrm{a}}$ & $0.861^{\mathrm{a}}$ & 0.06 \\
\hline \multicolumn{7}{|l|}{5 to $10 \mathrm{w}$} \\
\hline $\mathrm{ADG}(\mathrm{g})$ & $648^{\mathrm{b}}$ & $641^{\mathrm{b}}$ & $713^{\mathrm{a}}$ & $693^{\mathrm{a}}$ & $718^{\mathrm{a}}$ & 38 \\
\hline ADFI (g) & $1,436^{\mathrm{b}}$ & $1,424^{\mathrm{b}}$ & $1,562^{\mathrm{a}}$ & $1,602^{\mathrm{a}}$ & $1,549^{\mathrm{a}}$ & 56 \\
\hline $\mathrm{G}: \mathrm{F}$ & 0.451 & 0.450 & 0.457 & 0.433 & 0.464 & 0.03 \\
\hline \multicolumn{7}{|l|}{ Overall } \\
\hline $\operatorname{ADG}(\mathrm{g})$ & $568^{\mathrm{b}}$ & $570^{\mathrm{b}}$ & $658^{\mathrm{a}}$ & $643^{a}$ & $673^{\mathrm{a}}$ & 25 \\
\hline ADFI (g) & 1,025 & 1,041 & 1,122 & 1,138 & 1.140 & 51 \\
\hline G:F & 0.554 & 0.548 & 0.587 & 0.565 & 0.590 & 0.07 \\
\hline
\end{tabular}

${ }^{1} \mathrm{CON}=$ Basal diet; DP = Nasal diet+1 g/kg date pit; JH = Basal diet+0.5 g/kg Japanese-honeysuckle; HCT = Basal diet+1 g/kg Houttuynia cordata thumb; $\mathrm{LE}=$ Basal diet $+1 \mathrm{~g} / \mathrm{kg}$ laquer tree extract.

${ }^{2}$ Standard error. ${ }^{a, b}$ Means in the same row with different superscripts differ $(\mathrm{p}<0.05)$.

to 5, Dietary supplementation of $\mathrm{YG}$ and $\mathrm{HR}$ enhanced ( $\mathrm{p}<0.05)$ ADG. Beside, no difference was found, between YG and HR treatments. During, wk 5 to 10, higher ADG also was observed in $\mathrm{YG}$ and $\mathrm{HR}$ treatments $(\mathrm{p}<0.05)$. Additional, YG had the highest ADG $(p<0.05)$. There was always an increase on ADG in YG and HR $(\mathrm{p}<0.05)$ though all periods. There were no differences $(p>0.05)$ observed on $\mathrm{DM}, \mathrm{N}$ and energy digestibility among all treatments (Table 8).

Appearance of diarrhea : Effects of herbs on appearance of diarrhea in growing-finishing pigs were shown in Table 7. From d 0 to $\mathrm{d} 4, \mathrm{CON}$ treatment had higher diarrhoeal score compared to others $(p<0.05)$. The lowest diarrhea score were presented in HR treatment on $d$ 1.

Blood characteristic : During all the experiment periods, there were no differences ( $p>0.05$ ) observed on RBC, WBC, lymphocyte and $\mathrm{IgG}$ concentrations among all treatments

Table 5. Effect of anti-diarrhoeal herbs on appearance of diarrhea in weanling-growing pigs ${ }^{1}$

\begin{tabular}{lcccccc}
\hline Items & CON & DP & JH & HCT & LE & SE $^{2}$ \\
\hline $1 \mathrm{~d}$ & 17.9 & 16.6 & 18.3 & 16.1 & 16.4 & 1.45 \\
$2 \mathrm{~d}$ & $17.9^{\mathrm{a}}$ & $8.5^{\mathrm{b}}$ & $8.4^{\mathrm{b}}$ & $4.1^{\mathrm{c}}$ & $4.3^{\mathrm{c}}$ & 0.87 \\
$3 \mathrm{~d}$ & $11.2^{\mathrm{a}}$ & $4.0^{\mathrm{b}}$ & $4.1^{\mathrm{b}}$ & $0.7^{\mathrm{c}}$ & $0.6^{\mathrm{c}}$ & 0.82 \\
$4 \mathrm{~d}$ & $6.1^{\mathrm{a}}$ & $0.8^{\mathrm{b}}$ & $1.0^{\mathrm{b}}$ & $0.6^{\mathrm{b}}$ & $0^{\mathrm{b}}$ & 0.60 \\
$5 \mathrm{~d}$ & $1.3^{\mathrm{a}}$ & $0.3^{\mathrm{b}}$ & $0.2^{\mathrm{b}}$ & $0.2^{\mathrm{b}}$ & $0^{\mathrm{b}}$ & 0.30 \\
$6 \mathrm{~d}$ & $0.8^{\mathrm{a}}$ & $0.2^{\mathrm{b}}$ & $0^{\mathrm{b}}$ & $0^{\mathrm{b}}$ & $0^{\mathrm{b}}$ & 0.37
\end{tabular}

${ }^{\mathrm{CON}}=$ Basal diet; $\mathrm{DP}=$ Basal diet $+1 \mathrm{~g} / \mathrm{kg}$ date pit; $\mathrm{JH}=$ Basal diet +0.5 $\mathrm{g} / \mathrm{kg}$ Japanese-honeysuckle; HCT = Basal diet $+1 \mathrm{~g} / \mathrm{kg}$ Houttuynia cordata thumb; $\mathrm{LE}=$ Basal diet $+1 \mathrm{~g} / \mathrm{kg}$ laquer tree extract.

${ }^{2}$ Standard error.

${ }^{a, b, c}$ Means in the same row with different superscripts differ $(\mathrm{p}<0.05)$.
(Table 9).

Meat quality : No differences were observed on meat color, sensory evaluation (color, firmness, marbling), drip loss, cooking loss, $\mathrm{pH}$, water holding capacity (WHC) among all treatment groups (Table 10). However, pigs fed YG and HR diets had a higher $(\mathrm{p}<0.05)$ longissimusdorsi muscle area (LMA) than pigs fed CON diet.

\section{DISCUSSION}

Growth performance and apparent total tract digestibility

Recently, some researchers have conducted to

Table 6. Effect of anti-diarrhoeal herbs on growth performance in growing-finishing pigs $^{1}$

\begin{tabular}{lcccc}
\hline Items & CON & YG & HR & SE $^{2}$ \\
\hline 0 to $5 \mathrm{w}$ & & & & \\
ADG (g) & $751^{\mathrm{b}}$ & $837^{\mathrm{a}}$ & $819^{\mathrm{a}}$ & 12 \\
ADFI (g) & 1,972 & 2,107 & 2,075 & 58 \\
G:F & 0.381 & 0.397 & 0.395 & 0.01 \\
5 to $10 \mathrm{w}$ & & & & \\
ADG (g) & $858^{\mathrm{b}}$ & $933^{\mathrm{a}}$ & $914^{\mathrm{ab}}$ & 22 \\
ADFI (g) & 2,372 & 2,564 & 2,531 & 79 \\
G:F & 0.362 & 0.365 & 0.361 & 0.01 \\
Overall & & & & \\
ADG (g) & $805^{\mathrm{b}}$ & $885^{\mathrm{a}}$ & $867^{\mathrm{a}}$ & 12 \\
ADFI (g) & 2,172 & 2,336 & 2,303 & 54 \\
G:F & 0.371 & 0.379 & 0.377 & 0.01 \\
\hline
\end{tabular}

${ }^{1} \mathrm{CON}=$ Basal diet; $\mathrm{YG}=$ Basal diet $+1 \mathrm{~g} / \mathrm{kg}$ yellow ginger; $\mathrm{HR}=$ Basal diet $+1 \mathrm{~g} / \mathrm{kg}$ hoantchy root.

${ }^{2}$ Standard error.

${ }^{a, b}$ Means in the same row with different superscripts differ $(\mathrm{p}<0.05)$. 
Table 7. Effect of anti-diarrhoeal herbs on appearance of diarrhea in growing-finishing pigs ${ }^{1}$

\begin{tabular}{lllll}
\hline Items & CON & YG & HR & $\mathrm{SE}^{2}$ \\
\hline $1 \mathrm{~d}$ & $8.6^{\mathrm{a}}$ & $4.7^{\mathrm{b}}$ & $0.7^{\mathrm{c}}$ & 0.42 \\
$2 \mathrm{~d}$ & $5.4^{\mathrm{a}}$ & $2.1^{\mathrm{b}}$ & $0.5^{\mathrm{b}}$ & 0.77 \\
$3 \mathrm{~d}$ & $1.7^{\mathrm{a}}$ & $1.6^{\mathrm{a}}$ & $0.3^{\mathrm{b}}$ & 0.28 \\
$4 \mathrm{~d}$ & $0.2^{\mathrm{a}}$ & $0^{\mathrm{b}}$ & $0^{\mathrm{b}}$ & 0.12 \\
$5 \mathrm{~d}$ & 0 & 0 & 0 & 0 \\
$6 \mathrm{~d}$ & 0 & 0 & 0 & 0 \\
\hline${ }^{1} \mathrm{CON}=$ Basal diet; YG = Basal diet+1 g/kg yellow ginger; HR = Basal \\
diet+1 g/kg hoantchy root. \\
${ }^{2}$ Standard error. \\
${ }_{\mathrm{a}, \mathrm{b}, \mathrm{c}}$ Means in the same row with different superscripts differ (p<0.05).
\end{tabular}

investigate the effect of the supplementation herbs (Young et al., 2003; Basmacioglu et al., 2004; Govaris et al., 2004; Giannenas et al., 2005; Kong et al., 2007). However, the results were inconsistent, even the same species herb appeared the distinct results. Such as, Al-Yousef and Lyons (1995) observed date pits in broiler starting diets at levels ranging from 5 to $27 \%$, improved feed conversion. However, this study showed different results, no difference was observed through experimental period. Those different results may be due to the animal species. Relatively, the influence of different herbs on growth performance also presented different results. For instance, Janz et al. (2007) found that pigs preferred the feed supplemented with garlic or rosemary over the feed supplemented with oregano or ginger. Several experiments also showed the inconsistent impacts of the same anti-diarrhoeal herbs. For example, the study conducted by Chang et al. (2010) reported that inclusion of lacquer meal had no influences on growth performance of growing-finishing pigs at 20 and $40 \mathrm{~g} / \mathrm{kg}$ diet which was different from our results. During post weanling phase, incomplete development of intestinal tracts caused it easier to be invaded by pathogens than finishing pigs. There was another possibility. Basal dietary ingredients comprised different substance that interacted with supplementation herbs.

As the development of anti-diarrhoeal herbs added in

Table 8. Effect of anti-diarrhoeal herbs on digestibility nutriment in growing-finishing pigs ${ }^{1}$

\begin{tabular}{|c|c|c|c|c|}
\hline Items (\%) & $\mathrm{CON}$ & $\overline{Y G}$ & HR & $\mathrm{SE}^{2}$ \\
\hline \multicolumn{5}{|l|}{$5 \mathrm{w}$} \\
\hline DM & 77.27 & 80.77 & 78.72 & 1.11 \\
\hline $\mathrm{N}$ & 79.54 & 82.59 & 79.41 & 1.10 \\
\hline GE & 76.56 & 76.22 & 77.35 & 1.08 \\
\hline \multicolumn{5}{|l|}{$10 \mathrm{w}$} \\
\hline $\mathrm{DM}$ & 74.54 & 75.79 & 76.06 & 1.33 \\
\hline $\mathrm{N}$ & 75.33 & 77.96 & 73.49 & 1.71 \\
\hline GE & 72.94 & 74.96 & 75.01 & 1.54 \\
\hline
\end{tabular}

Table 9. Effect of anti-diarrhoeal herbs on blood characteristic in growing-finishing pigs ${ }^{1}$

\begin{tabular}{lrrrr}
\hline Items & CON & \multicolumn{1}{c}{ YG } & \multicolumn{1}{c}{$\mathrm{HR}$} & \multicolumn{1}{c}{$\mathrm{SE}^{2}$} \\
\hline $5 \mathrm{w}$ & & & & \\
$\mathrm{RBC}\left(10^{6} / \mu \mathrm{l}\right)$ & 6.77 & 6.83 & 6.97 & 0.11 \\
$\mathrm{WBC}\left(10^{3} / \mu \mathrm{l}\right)$ & 15.78 & 17.06 & 16.16 & 0.59 \\
Lymphocyte $(\%)$ & 64.65 & 62.33 & 65.17 & 1.64 \\
$\mathrm{IgG}(\mathrm{g} / \mathrm{dl})$ & 969.7 & 988.2 & 984.2 & 43.98 \\
$10 \mathrm{w}$ & & & & \\
$\mathrm{RBC}\left(10^{6} / \mu \mathrm{l}\right)$ & 7.23 & 7.32 & 7.46 & 0.07 \\
$\mathrm{WBC}\left(10^{3} / \mu \mathrm{l}\right)$ & 17.81 & 17.19 & 17.68 & 0.43 \\
$\mathrm{Lymphocyte}(\%)$ & 66.49 & 65.20 & 64.03 & 1.24 \\
$\mathrm{IgG}(\mathrm{g} / \mathrm{dl})$ & $1,003.3$ & $1,051.3$ & $1,014.7$ & 15.66
\end{tabular}

${ }^{1} \mathrm{CON}=$ Basal diet; $\mathrm{YG}=$ Basal diet $+1 \mathrm{~g} / \mathrm{kg}$ yellow ginger; $\mathrm{HR}=$ Basal diet $+1 \mathrm{~g} / \mathrm{kg}$ hoantchy root.

${ }^{2}$ Standard error.

diets, we pay more attention on major bioactive compounds of herbs. For example, saponin that was one of major bioactive compounds of Japanese honeysuckle (Suh et al., 2005). In addition, Tong et al. (2004) reported that a natural extract known as saponins promoted growth performance in broiler chickens and weaning pigs, and the conclusion is in agreement with current results. Houttuynia cordata is a traditional medicinal plant that is used in herbal preparations in Asian countries to relieve inflammatory conditions (Jee et al., 2010). Flavonoid which exist Houttuynia cordata, exhibit a wide range of biological effects, such as anti-inflammatory, anti-allergic, anti-virus, anti-bacteriaand anti-oxidation (Jian et al., 1986). Flavonoid in soy genistein, at dietary concentrations of 200 to 400 ppm is an orally active immune modulator that enhances systemic serum virus elimination and body growth in

Table 10. Effect of anti-diarrhoeal herbs on meat quality in growing-finishing pigs ${ }^{1}$

\begin{tabular}{|c|c|c|c|c|}
\hline Items & $\mathrm{CON}$ & YG & HR & $\mathrm{SE}^{2}$ \\
\hline \multicolumn{5}{|l|}{ CIE } \\
\hline $\mathrm{L}^{*}$ & 57.71 & 58.44 & 57.33 & 0.811 \\
\hline$a^{*}$ & 17.35 & 17.49 & 17.78 & 0.337 \\
\hline$b^{*}$ & 8.22 & 8.29 & 8.35 & 0.390 \\
\hline \multicolumn{5}{|l|}{ Sensory evaluation } \\
\hline Color & 3.25 & 3.31 & 3.25 & 0.108 \\
\hline Firmness & 3.06 & 3.13 & 3.19 & 0.096 \\
\hline Marbling & 3.13 & 3.25 & 3.19 & 0.130 \\
\hline Drip loss (\%) & 7.27 & 7.20 & 7.33 & 0.442 \\
\hline Cooking loss (\%) & 27.17 & 26.72 & 27.30 & 0.973 \\
\hline $\mathrm{pH}$ & 6.05 & 6.04 & 6.07 & 0.017 \\
\hline $\begin{array}{r}\text { Water holding } \\
\text { capacity }(\%)\end{array}$ & 54.81 & 55.90 & 54.56 & 1.349 \\
\hline $\operatorname{LMA}\left(\mathrm{cm}^{2}\right)$ & $48.06^{\mathrm{b}}$ & $49.81^{\mathrm{a}}$ & $49.65^{\mathrm{a}}$ & 0.384 \\
\hline
\end{tabular}


virally challenged pigs (Greine et al., 2001). In this study, houttuynia cordata thumb was beneficial for growth performance, especially during 0 to 5 wks. It indicated flavonoid was able to promoted growth performance by ensuring a well ecosystem of gastrointestinal microbitota. Those trials also illuminated bioactive ingredient determinated herbs' property. However, the interaction of different bioactive ingredients leaded to diverse influences generally. To our knowledge specific mechanisms were unclean, further experiments were always requisite.

Compare the influence of the four kinds of herbs in current experiment on growth performance in weanlinggrowing pigs, no difference was found except DP. This finding was suggested that JH, HCT, LE might be growth promotor. Additionally, it confirmed previous conclusion that herbs had an ability to enhance growth performance (Guo et al., 2004; Namkung et al., 2004; Kong et al., 2007). However, the appropriate quantity and functional mechanism of those herbs were indistinct. Thereby, our study laid a foundation for the further experiments to utilize anti-diarrhoeal herbs supplementation in pigs.

Although both of yellow ginger and hoantchy root are regarded as Chinese traditional medicine to antiinflammatory, increasing appetite for a long time, there has been little research on them as a feed additive to growingfinishing pigs. Janz et al. (2007) reported that the essential oils $(500 \mathrm{mg} / \mathrm{kg})$ from ginger had no effect on growth performance and dressing percentage of finisher pigs. In contrast, the current study presented different results. It's indicated unpurified extracts contain a number of different molecules extracted with certain solvent, which can affect the action of each other. In current observation, hoantchy root affected growth performance. It probably resulted from that hoantchy root were against gram-positive bacteria (Joseph, 1956). It guaranteed healthy gastrointestinal tracts to accelerate a well growth performance. Unclear specific mechanism, and no more study to be compared, further studies are needed to determine the effects.

In additions, herbs enhanced the intestinal tract health which could lead to the improving nutriment digestibility, Wang et al. (2007) found that supplemental herb mainly included Zizyphi spinosae (Spina Date Seed) 10\%, pollen pini $5 \%$ treatments on pigs yielded better digestibility of $\mathrm{DM}$ and $\mathrm{N}$ at 4 wks. However, the current study appeared results, that herbs not affected apparent digestibility of DM, N. Manzanilla et al. (2006) got a similar result with us. Avilamycin improved feed efficiency in spite of a lower total tract digestibility of DM. Indeed, some experiments had revealed the effects of herbs on digestibility were not significant (Ao et al., 2011). It is probably a consequence that herbs accelerate the digestion and shorten the time of feed passage through the digestive tract (Platel et al., 2001; Suresh and srinivasan, 2007). Many results are inconsistent and controversial, further experiments are in requirement.

\section{Appearance of diarrhea}

In current study, except date pits, no difference was found on the effects of anti-diarrhoeal. The other herbs included Japanese-honeysuckle, houttuynia cordata Thumb, laquer tree extract, yellow ginger and hoantchy root which were documented owning the antioxidant, antimicrobial or anti-diarrhoeal property (Chen et al., 2003; Joshua et al, 2005; Irena et al., 2008; Zhang et al., 2009; Kim et al., 2010). Besides, antioxidant, prevent the villus cells shedding to keep villus height, in order to protecting intestinal integrality, enhancing resistance, reducing appearance of diarrhea (Sies, 1991). As we known, Escherichia coli, which adhere to the small intestinal microvilli and produce enterotoxins that act locally on enterocytes (Mackinnon, 1998) play an important role against diarrhea. Nevertheless, antimicrobial ability limited the proliferation of E. coli (Cutter et al., 2000). Pasqua et al. (2006) found a change in long chain fatty acid profile in the membranes of $E$. coli grown in the presence of limonene or cinnamaldehyde. It was consistent with current study that supplementation of herbs decreased the appearance of diarrhea significant. As for date pits, it may be caused by dietary fibre, which regulate intestinal peristalsis, promote comfortable digestion. Or functional components selenium that presented in date pits can be used as antidiarrhea (thus antic-arcinogenic) in human therapeutics (Pszczola et al., 1998).

\section{Blood characteristic}

The study of Kazeem et al. (2011) found the basal diet added ginger at the levels $2.5 \%, 5 \%, 10 \%$ respectively, were inability to influence WBC, RBC, and lymphocyte in rats. The current study was agreement with this result. No difference in WBC, RBC and lymphocyte were observed in YG and HR treatments compared with control treatment. In contrast, Kong et al. (2007) reported that dietary supplementation with Chinese herbal ultra-fine powder enhanced serum concentrations of IL-2, IL-6, TNF- $\alpha$, IgG, IgM and lymphocytes in early-weaned piglets. Anna et al. (2009) reported herbs can increase the amounts of RBC and lymphocyte, and decrease WBC's amounts. It implicated a better metabolization and immunity. Leea et al. (2007) confirmed this consequence, whose study displayed methanol extracts of dandelion root was able to increase the amounts of lymphocyte in chicken. However, basal diet with YG (yellow ginger), HR (hoantchy root) didn't differ in the $\mathrm{WBC}, \mathrm{RBC}$ and lymphocyte with control group. Flavones that were bioactive substance of $\mathrm{YG}$ and $\mathrm{HR}$ had been documented that were unable to affect the amounts of WBC and lymphocyte in rats supplemented at 2.5, 5, 10 levels (Kazeem et al., 2011). However, the study have been 
conducted by Greiner (2001), which revealed flavones in soy genistein could improve the biological response of animals to pathogens and vaccines. It may be related to capacity to affect intercellular signaling of immune cells and the ability to arrest the virus to replicate or attach. However, to the best of our knowledge, limited scientific information is available to justify reputed utilization of yellow ginger and hoantchy in swine diet.

\section{Meat quality}

Organic farming systems, which have been invested by The European Union, use no chemical products both on the crop or phytogenic feed on the animals. The one of all reasons was that phytogenic feed or additives could improve meat quality (Morbidini et al., 2001). Such as, the experiment was conducted by Ao et al. (2011) indicated that red ginseng can increase LMA, enhance WHC, decrease drip loss at supplementation at the level 1, 2, $4 \mathrm{~g} / \mathrm{kg}$ fermented red ginseng. Similarly, yellow ginger was capable of affecting meat quality by different ways. Such as ginger at level of $0.5 \%$ which was used for improving meat quality by post-slaughter handling appeared to be the optimum level to achieve the best tenderization effect (Naveena, 2004). However, Janz et al. (2007) didn't believe that it improved meat quality by adding ginger into diets barely. In current study, there is no difference between the treatment group of $\mathrm{FH} 1, \mathrm{FH} 2$ and control group, except LMA. LMA can reflect the ratio of lean meat indirectly. The influence of herbs on fat metabolism that had been demonstrated it could depress the hepatic activities of lipogenic and cholesterogenic enzyme (Stephen et al., 1993). As to bioactive ingredients, the both of yellow ginger and hoantchy root comprised flavones, the property of which can increase the concentration of HDL (high-density lipoprotein) (Wei et al., 2008). Additionally, there was a negative relationship between triglycerides and HDL in plasma. Consequently, flavones decreased triglycerides in according to influence lipid's metabolism.

In conclusion, supplementation of anti- diarrhoeal herbs in pig diets can prevent diarrhea of pigs, improve growth performance in pigs and increased LMA of finishing pigs.

\section{ACKNOWLEDGEMENT}

The authors would like to acknowledge the financial assistance (No. PJ0081212012 of Bio-Green 21 and PJ0084942012 of $15 \mathrm{G}$ Agenda) provided by the Rural Development Administration of Korea.

\section{REFERENCES}

AOAC. 1995. Association of official analytical chemists, Official Method of Analysis. 16th
Anna, Z., K. Edyta, R. Eugenius and P. Grela. 2009. The effect of a herbal extract used in pig fattening on the animals' performance and blood components. Annales Universitatis mariae curieskł odowska lublinpolonia. 27-33.

Ao, X., Q.W. Meng and I. H. Kim. 2011. Effects of fermented red ginseng supplementation on growth performance, apparent nutrient digestibility, blood hematology and meat quality in finishing pigs. Asian-Aust. J. Anim. Sci. 24:525-531.

Al-Yousef, Y., J. M. Vandepopuliere and J. M. Lyons. 1995. Dates and date pits as ingredients in broiler starting and Coturnix quail breeder diets. Poult. Sci. 74:1134-1142.

Basmacioglu, H., O. Tokusoglu and M. Ergul. 2004. The effect of oregano and rosemary essential oils or alpha-tocopheryl acetate on performance and lipid oxidation of meat enriched with n-3 PUFAs in broilers. S. Afr. J. Anim. Sci. 34:197-210.

Manzanilla, I., M. Castillo, S. M. M. Martín-Orúe, E. G. Roca, J. F.Badiola and J. Gasa. 2006. The response of gastrointestinal microbiota to avilamycin, butyrate and plant extracts in earlyweaned pigs. J. Anim. Sci. 84:2725-2734.

Chang, H. S., S. K. Jin, S. Prashant, W. K. Young, H. K. Kwang, K Kyung, M. K. Sun, K. L. Sung and J. C. Byung. 2010. Effect of inclusion of Lacquer (Rhus verniciflua Stokes) meal on carcass traits and meat quality in growing-finishing pigs. ALRIC. 30:597-602.

Chen, Y. Y., J. F. Liu, C. M. Chen, P. Y. Chao and T. J. Chang. 2003. A study of the antioxidative and antimutagenic effects of Houttuynia cordata Thunb using an oxidized frying oil-fed model. J. Nutr. Sci. Vitaminol. 49:327-333.

Greiner, L. L., T. S. Stahly and T. J. Stabel. 2001. The effect of dietary soy genistein on pig growth and viral replication during a viral chanllenge. J. Anim. Sci. 79:1272-1279.

Cutter and N. Catherine. 2000. Antimicrobial effect of herb extracts against Escherichia coli, Listeria monocytogenes, and Salmonella typhimurium associated with beef. J. Food Prot. 63:601-607.

Giannenas, I. A., P. Florou, N. A. E. Botsoglou and A. B. Spais. 2005. Effect of supplementing feed with oregano and (or) alphatocopheryl acetate on growth of broiler chickens and oxidative stability of meat. J. Anim. Feed Sci. 14:521-535.

Govaris, A., N. Botsoglou, G. Papageorgiou, E. Botsoglou and I. Ambrosiadis. 2004. Dietary versus post-mortem use of oregano oil and (or) alpha-tocopherol in turkeys to inhibit development of lipid oxidation in meat during refrigerated storage. Int. J. Food Sci. Nutr. 55:115-123.

Guo, F. C., R. P. Kwakkel, J. Soede, B. A. Williams and M. W. Verstegen. 2004. Effect of a Chinese herb medicine formulation, as an alternative for antibiotics, on performance of broilers. Br. Poult. Sci. 45:793-797.

Hitoyasu, F., L. A. Eader and K. L. Komschlies. 1991. Flacone acetic acid directly induces expression of Cytokirne genes in mouse splenic leukocytes but not in hunman peripheral blood leukocytes. Cancer Res. 51:6596-6602.

Hong, D. H., S. B. Han, C. W. Lee, S. H. Park, Y. J. Jeon, M. J. Kim, S. S. Kwak and H. M. Kim. 1999. Cytotoxicity of urushiols isolated from sap of Korean lacquer tree (Rhusverniciflua Stokes). Arch. Pharm. Res. 22:638-641.

Honikel, K. O. 1998. Reference methods for the assessment of physical characteristic of meat. Meat Sci. 49:447-457.

Hoshi, S., A. Ushino, N. Saito, K. I. Kusanagi, T. Ihara and S. 
Ueda. 1999. Comparison of adjuvants with respect to serum IgG antibody response in orally immunized chickens. Comp. Immunol. Microbiol. Infect. Dis. 22:63-69.

Huo, S. Y., Y. R. Li and C. M. Li. 2004. Study on influence of traditional Chinese medicine feed additive on digestion and absorption. AJTCVM. 4:16-19.

Irena, P. I., A. J. Heinrich, B. A. R. Petr and M. Petr. 2008. Constituents and antimicrobial properties of blue honeysuckle: A novel source for phenolic antioxidants. J. Agric. Food Chem. 56:11883-11889.

Janz, J. A. M., P. C. H. Morel, B. H. P. Wilkinson and R. W. Purchas. 2007. Preliminary investigation of the effects of lowlevel dietary inclusion of fragrant essential oils and oleoresins on pig performance and pork quality. Meat Sci. 75:350-355.

Jian, J. W. and Q. X. Xiao. 1986. Phytomedicine effective component book. People's Hygiene Press. Beijing.

Jee, Y. C., A. L. Jung, B. L. Jee, J. Y. Sook and C. L. Seung. 2010 Anti-inflammatory activity of Houttuynia cordata against lipoteichoic acid-induced inflammation in human dermal fibroblasts. Chonnam Med. J. 46:140-147.

Joseph, M. 1956. Chinese herbal medicine - Recent studies. Econ. Bot. 10:42-48.

Joshua, K. K., Y. L. L. Flora and P. L. C. Andrew. 2005. Amelioration of experimental colitis by Astragalus membranaceus through anti-oxidation and inhibition of adhesion molecule synthesis. World J. Gastroenterol. 11:57875794.

Jung, N. C. 1998. Biological activity of urushiol and flavonoidsfrom Lac tree (Rhus verniciflua Stokes). Ph.D. Thesis, Chonnam National University, Kwang-ju, South Korea.

Kazeem, M. I., H. A. Bankole and A. A. Fatai. 2011. Protective effect of ginger in normal and carbon-tetrachloride induced hepatotoxic rats. Ann. Biol. Res. 2:1-8.

Kauffman, R. G., G. Eikelenboom, P. G. Van derWal, B. Engel and M. Zaar. 1986. Acomparison of methods to estimate waterholding capacity in post-rigorporcine muscle. Meat Sci. 18:307-322.

Kim, J. S., Y. S. Kwon, W. J. Chun, T. Y. Kim, J. Sun, C. Y. Yu and M. J. Kim. 2010. Rhus verniciflua Stokes flavonoid extracts have anti-oxidant, anti-microbial and $\alpha$-glucosidase inhibitory effect. Food Chem. 120:539-543.

Kohler, E. M. and H. Moon. 1984. Enteric colibacillosis of newborn pigs. Purdue University Coop. Ext. Ser. PIH-30, West Lafayette.

Kyriakis, S. C., V. K. Tsiloyiannis, J. Vlemmas, K. Sarris, A. C. Tsinas, C. Lexopoulos and L. Jansegers. 1999. The effect of probiotic LSP 122 on the control of post-weaning diarrhoea syndrome of piglets. Res. Vet. Sci. 67:223-228.

Kong, X. F., G. Y. Wu, Y. P. Liao, Z. P. Hou, H. J. Liu, F. G. Yin, T. J. Li, R. L. Huang, Y. M. Zhang, D. Deng, P. Kang, R. X. Wang, Z. Y. Tang, C. B. Yang, Z. Y. Deng, H. Xiong, W. Y. Chu, Z. Ruan, M. Y. Xie and Y. L. Yin. 2007. Effects of Chinese herbal ultra-fine powder as a dietary additive on growth performance, serum metabolites and intestinal health in early-weaned piglets. Livest. Sci. 108:272-275.

Kong, X. F, Y. Yin, G. Y. Wu, H. J. Liu, F. G. Yin, T. J. Li, R. L. Huang, Z. Ruan, H. Xiong, Z. Deng, M. Y. Xie, Y. Liao and S. W. Kim. 2007. Dietary supplementation with acanthopanax senticosus extract modulates cellular and humoral immunities in weaned piglets. Asian-Aust. J. Anim. Sci. 20:1453-1461.

Kong, X. F, G. Y. Wu, Y. P. Liao, Z. P. Hou, H. J. Liu, F. G. Yin, T. J. Li, R. L. Huang, Y. M. Zhang, D. Deng, M.Y. Xie, Z. Y. Deng, H. Xiong, Z. Ruan, P. Kang, C. B. Yang, Y. L. Yin and M. Z. Fan. 2007. Dietary supplementation with Chinese herbal ultra-fine powder enhances cellular and humoral immunity in early-weaned piglets. Livest. Sci. 108: 94-98.

Leea, S. H., B. Hyun, H. K. Chuna, H. J. Parka, S. M. Choa and Y. M. Leea. 2007. In vitro treatment of chicken peripheral blood lymphocytes, macrophages, and tumor cells with extracts of Korean medicinal plants. Nutr. Res. 27:362-366.

Mackinnon, J. D. 1998. Enteritis in the young pig caused by Escherichia coli. Pig J. 41:227-255.

Mao, F. X., F. X. Piao, C. H. Lai, D. F. Li, J. J. Xing and B. L. Shi. 2005. Effects of $\beta$-glucan obtained from the Chinese herb Astragalus membranaceus and lipopolysaccharide challenge on performance, immunological, adrenal, and somatotropic responses of weanling pigs. J. Anim. Sci. 83:2775-2782.

Mohamed, A. A. and Y. L. Chang. 2007. Optimization of phenolics and dietary fibre extraction from date seeds. Food Chem. 108: 977-985

Morbidini, L., D. M. Sarti, P. Pollidori and V. Valigi. 2001. Carcass, meat and fat quality in Italian Merino derived lambs obtained with "organic" farming systems. J. Food Compos. Anal: 29-33.

NPPC. 2000. Pork composition and quality assessment procedures. In: National (Ed. E. P. Berg). Pork Producers Council. Des. Monies. 1-38.

Nabuurs, M. J. A. 1995. Microbiological, structural and functional changes of the small intestine of pigs at weaning. Pig News Inf. 16:93-97.

Nakatani, N. 2000. Phenolic antioxidants from herbs and spices. Biofactors 13:141-146.

Namkung, H., M. Li, J. Gong, H. Yu, M. Cottrill and C. F. M. de Lange. 2004. Impact of feeding blends of organic acids and herbal extracts on growth performance, gut microbiota and digestive function in newly weaned pigs. Can. J. Anim. Sci. 84:697-704

Naveena, B. M. 2004. The tenderization of buffalo meat using ginger extract. J. Muscle Foods 15:235-244.

NRC. 1998. Nutrient requirement of pigs, National Research Council, 10th ed. Academy Press, Washington, DC, USA.

Pasqua, R. D., N. Hoskins, G. Betts and G. Mauriello. 2006. Changes in membrane fatty acids composition of microbial cells induced by addiction of thymol, carvacrol, limonene, cinnamaldehyde, and eugenol in the growing media. J. Agric. Food Chem. 54:2745-2749.

Platel, K. and K. Srinivansan. 1996. Influence of dietary spices or their active principles on digestive enzymes of small intestinal mucosa in rats. Int. J. Food Sci. Nutr. 47:55-59.

Platel, K. and K. Srinivasan. 2001. Studies on the influence of dietary spices on food transit time in experimental rats. Nutr. Res. 21:1309-1314.

Pszczola, D. 1998. The ABs of nutraceutical ingredients. Food Technol. 52:30-37.

SAS. 1996. SAS user's guide. Release 6.12 Editions. SAS Institute. Inc, Cary CON. USA.

Si, W., J. Gong, R. Tsao, T. Zhou, H. Yu, C. Poppe, R. Du and Z. Johnson. 2006. Antimicrobial activity of essential oils and 
structurally related synthetic food additives towards selected pathogenic and beneficial gut bacteria. J. Appl. Microbiol. 100: 296-305.

Sies. H. 1991. Oxidative stress: From basic research to clinical application. Am. J. Med. 91:31-38.

Stephen, W., S. Russell, M. D. Kamer, L. Steven and M. D. Sivak. 1993. Effects of garlic on total serum cholesterol. Ann. Intern. Med. 119:599-605.

Suh, S. C., S. G. Cho, J. H. Hong and Y. H. Choi. 2005. Extraction characteristics of flavonoids from Lonicera flos by supercritical fluid carbon dioxide $\left(\mathrm{SF}-\mathrm{CO}_{2}\right)$ with $\mathrm{CO}$ solvent Korean J. Food Sci. Technol. 37:183-188.

Suresh, D. and K. Srinivasan. 2007. Studies on the in vitro absorption of spice principles curcumin, capsaicin and piperine in rat intestines. Food Chem. Toxicol. 45:1437-1442.

Tong, J. M., R. N. Sa, Z. W. Shan, X. M. Zhu and Q. Zhang. 2004 Effect of polysavone on performance in broiler chickens and weaning pigs. Chin. Anim. Husb. Vet. Med. 31:19-21.

Wang, Y., Y. J. Chen, J. H. Cho, J. S. Yoo, Q. Wang, Y. Huang, H. J. Kim and I. H. Kim. 2007. The effects of dierary herbs and coral mineral complex on growth performance, nutrient digestibility, blood characteristics and meat quality in finishing pigs. J. Anim. Feed Sci. 16:397-407.

Wei, A. and T. Shibamoto. 2007. Antioxidant activities and volatile constituents of various essential oils. J. Agric. Food Chem. 55: $1737-1742$.
Wei, J., G. Lei, J. Lian and B. Q. Gong. 2008. Hypolipidaemic mechanisms of action of CM108 (flavone derivative) in hyperlipidaemic rats. J. Pharm. Pharmacol. 260:1207-1212.

Wilson, A. D., C. R. Stoke and J. Boure. 1989. Effect of age on absorption and immune responses to weaning or introduction of novel dietary antigens in pigs. Res. Vet. Sci. 46:180-186.

Windisch, W., K. Schedle, C. Plitzner and A. Kroismayr. 2008. Use of phytogenic products as feed additives for swine and poultry. J. Anim. Sci. 86:140-148.

Yen, J. T. and W. G. Pond. 1993. Effects of carbadox, copper and Yucca shidigera extract on growth performance and visceral weight of young pigs. J. Anim. Sci. 71:2140-2146.

Yin, F. G., Y. L. Yin, X. F. Kong, Y. L. Li, Q. H. He, T. J. Li, R. L. Huang, Y. Q. Hou, X. G. Shu, L. X. Tan, L. X. Chen, J. H. Gong, S. W. Kim and G. Y. Wu. 2008. Dietary supplementation with acanthopanax senticosus extract modulates gut microflora in weaned piglets. Asian-Aust. J. Anim. Sci. 21:1330-1338.

Young, J. F., J. Stagsted, S. K. Jensen, A. H. Karlsson and P. Henckel. 2003. Ascorbic acid, alpha-tocopherol, and oregano supplements reduce stress induced deterioration of chicken meat quality. Poult. Sci. 82:1343-1351.

Zhang, G. F., Z. B.Yang, Y. Wang, W. R. Yang, S. Z. Jiang and G. S Gai. 2009. Effects of ginger root (Zingiber officinale) processed to different particle sizes on growth performance, antioxidant status, and serum metabolites of broiler chickens. Poult. Sci. 88:2159-2166. 